\title{
A democratização na evolução do pensamento político de Georges Lukács
}

\author{
Democratization in the evolution of political thinking by Georges Lukács \\ LUCI FARIA PINHEIRO (1) \\ Universidade Federal Fluminense (UFF), Niterói, Rio de Janeiro, Brasil.
}

RESUMO - O texto aborda a política em Lukács como processo de democratização de caráter radicalmente socialista e como postura filosófica marxista, onde a dialética é o método para exercer a crítica da realidade sobre a qual o homem desenvolve, através do trabalho, alternativas de emancipação, ao mesmo tempo em que estabelece os meios para atingir suas finalidades. A política é uma dimensão da práxis de domínio do homem sobre a natureza, nos limites que encontra no cotidiano e de acordo com as condições sócio-históricas e o grau de desenvolvimento econômico, onde a influência de Lênin é importante. Foi utilizada uma análise histórica de base bibliográfica e intercâmbios com intelectuais da mesma tradição, relacionando as fases do pensamento político e filosófico com as experiências políticas do pensador na Hungria e na Rússia.

Palavras-chave: Evolução. Pensamento politico. Democratização. Cotidiano. Georges Lukács.

ABSTRACT - The text deals with politics in Lukács as a process of democratization of a radically socialist character and as a Marxist philosophical position, where dialectics is the method to exercise the critique of reality over which man develops, through labor, alternatives of emancipation, at the same time in which it establishes the means to achieve its purposes. Politics is a dimension of the praxis of man's dominion over nature, within the limits he finds in everyday life and in accordance with socio-historical conditions and the degree of economic development where Lenin's influence is important. A historical analysis of bibliographical basis and exchanges with intellectuals of the same tradition was used, relating the phases of political and philosophical thinking with the political experiences of the thinker in Hungary and Russia.

Keywords: Evolution. Political thought. Democratization. Quotidian. Georges Lukács. 


\section{Introdução}

U

m marco na trajetória política e filosófica de Georges Lukács é seu ingresso no movimento operário e, logo depois, no Partido Comunista Húngaro ( $\mathrm{PCH}$ ) e no governo socialista da República dos Conselhos, na Hungria. A renúncia à abundância de uma elite financeira no meio familiar e às tradições acadêmicas alemãs onde teve sua formação literária e filosófica, é fundamental para se entender o anticapitalismo que caracteriza sua guinada à esquerda do partido e a democracia radical que sustenta até o final de sua vida. Ela se sedimenta ao longo de um percurso político marcado por exílios, punições, retrações e publicações tardias de sua vasta produção intelectual.

A produção marxista se fixa durante o primeiro exílio, em Viena, no período de 1919 a 1930, onde o partido funciona clandestinamente e seus membros, são continuamente ameaçados de deportação pelo ditador Horty que, na Hungria, derrota o modelo de democracia que Lukács teve como base na sociedade civil organizada. O segundo exílio de Lukács ocorre em Moscou, e suas reflexões políticas sobre a democracia se adensam no período stalinista, onde é característico o abandono do pensamento de Lênin.

A convicção em torno à importância de resgatar a originalidade do pensamento de Marx, Engels e Lênin, orienta sua contribuição ao "renascimento do marxismo". No período de maturidade, a abordagem democrática de Lukács se integra à ontologia marxista sem, contudo, inseri-la em sua obra final de definição dos pressupostos de uma ética marxista. Por isso, seu pensamento político não tem um lugar na filosofia contemporânea, nem na teoria política clássica, seria antes uma síntese ou parte de um legado a ser aprofundado, sobretudo em relação à crítica da democracia burguesa, que deve ser preliminar e também permanente no socialismo. Essa crítica é decorrente dos grandes conflitos mundiais vividos de perto pelo pensador, associado ao surgimento do proletariado como um novo sujeito histórico.

Lukács nasceu em 1885 e morreu em 1971, em Budapeste, Hungria. Sua formação universitária se deu na Universidade de Berlim entre 1909 e 1910 e na Universidade de Heidelberg, entre 1913 e 1917. O acesso ao melhor da cultura de seu tempo influenciou decisivamente a sólida e instigante produção no campo da estética e da filosofia marxista.

A renúncia ao mundo das finanças e à elite acadêmica alemã, é um pressuposto para se entender o anticapitalismo de Lukács seu engajamento na esquerda do partido, logo, para sua concepção de democracia socialista. Alguns aspectos de não ruptura entre o jovem marxista e o filósofo da maturidade tem como contraponto o positivismo e a social-democracia alemã, esta que, segundo Avron (1968), parte de uma interpretação revolucionária do marxismo, mas o reduz a um certo determinismo material, onde a história independe da vontade humana.

Outro elemento importante é sua radical crítica ao capitalismo e intransigência em relação ao nazismo na Alemanha e seus desdobramentos na Europa, durante e após a Segunda Guerra Mundial. Nesta trilha, Lukács na filosofia alemã, a partir dos meados do século XIX, um sentido autodestruidor da filosofia e da ciência burguesas.

O percurso filosófico e político não estava desvinculado do romantismo revolucionário de juventude que Lukács trouxe em Teoria do Romance e A Alma e as formas. Sua obra mais conhecida, "História e Consciência de Classe (HCC)" (1923), apesar dos traços idealistas, foi um fermento para a intelectualidade socialista. Propomos resgatar no presente a visão de democracia do filósofo em seu tempo histórico, recuperando elementos de continuidade e de superação dialética, sem estabelecer uma cronologia linear.

\section{A defesa da dialética em História e Consciência de Classe}

Há na constituição histórica do pensamento de Georges Lukács uma associação muita íntima entre estética, política e filosofia. Quase totalidade dos estudos realizados contribui para uma compreensão da política, cuja abordagem do autor é materialista e tais esferas do conhecimento se imbricam contemporizadas com as lutas de resistência ao capitalismo e o surgimento do sujeito revolucionário, o proletariado consciente. 
O ativismo político é a base de sua visão de maturidade, embora a cultura acumulada, não apenas qualifica o pensamento de Lukács como lhe garante uma originalidade estética e filosófica muito apreciada desde cedo no meio intelectual europeu.

Por isso, os nexos entre os textos de juventude e os de maturidade perfazem um longo percurso autêntico, tendo como ponto culminante a repercussão de História e Consciência de Classe, primeira obra marxista de Lukács, inscrita na fase de realismo revolucionário, ao lado de Tática e Ética; Lênin e o problema da dialética, assim como, Teses de Blum, textos produzidos no período de adesão ao $\mathrm{PCH}$ e durante o exílio de Viena. O pressuposto dialético aparece no texto Moses Hess e os problemas da Dialética idealista (1926), se mantendo em O Jovem Hegel, em Destruição da Razão e outros textos importantes de maturidade.

Nicolas Tertulian, pesquisador francês oriundo e formado na Romênia, dedicou-se ao estudo da estética de Lukács ao longo de toda sua carreira. Em seu livro mais recente, Pourquoi Lukács? (2016), o autor revela a impressão causada pela visão de componentes do pensamento de Lukács, a exemplo da história, da ideologia e da relação entre particularidade e universalidade.

Com a publicação d'A Estética e da Ontologia do Ser Social, pode-se descobrir o quanto as visões literárias de Lukács (inclusive seus julgamentos estéticos pontuais, como a grande admiração por Thomas Mann ou sua poderosa revirada a respeito da obra de Kafka) eram intimamente associadas a um pensamento preciso sobre a história, à uma crítica rigorosamente elaborada das ideologias de seu tempo e sobretudo a uma interpretação ontológica da condição humana (mesmo se ele recusava a utilização deste último conceito pelo medo de sair da realidade do gênero humano de seu contexto histórico e social). Ele se apoiava sobre uma dialética da particularidade e da universalidade que celebrava a pura imanência na auto-afirmação das forças humanas. (...) Seu julgamento estético fazia apelo à forte presença da "consciência de si do gênero humano", da Gattungsmässigkeit (TERTULIAN, 2016, p. 95).

Qualquer comparação entre $\mathrm{HCC}$ e a obra de maturidade Ontologia do Ser Social, seria inconsistente. O primeiro texto teve uma repercussão positiva incomparável com as mais recentes publicações que compreendem a Ontologia. Por outro lado, o amadurecimento intelectual de Lukács, em um século de grandes transformações, trouxe lições e desafios ao "renascimento do marxismo" que norteia sua visão de maturidade.

A maioria de seus textos resultou de uma sobrevivência à Primeira e à Segunda Guerra Mundial, e às revoluções socialistas na Rússia, Alemanha e Hungria até os meados do século XX. Lukács enfrenta os riscos de viver verdadeiramente as aventuras de um revolucionário de trincheira, riscos tanto à sua integridade física, familiar e, política, quanto intelectual, dos quais testemunha sua atitude incompreensível a muitos intelectuais, ao tornarem-se públicos os seus escritos do período stalinista e ainda, após se declinar de algumas ideias condenadas pelo partido.

O significado das polêmicas levantadas quando da publicação de HCC, observado pelo editor francês de 1960, tem centralidade no pensamento marxista do século XX, mas aborda história e consciência sem analisar a classe proletária, por isso fora ignorado por todas as grandes tendências políticas da época. Nas palavras de Axelos (apud LUKÁCS, 1960, p. 5) "este livro herético exerceu contudo uma considerável influência subterrânea. Ele marcou fortemente correntes e movimentos da pesquisa filosófica, sociológica, psicológica, e psicopatológica".

A crítica a $H C C$ que mais atingiu o filósofo manifestou-se na fração adversária do $\mathrm{PCH}$, com destaque para o grupo de Bela Kun e Rudas, por ocasião de uma reunião dos húngaros em Moscou, que na ausência de Lukács, combatem o livro como idealista. A revanche do filósofo viria muito mais tarde com Reboquismo e Dialética.

Segundo Laszlo llés, editor do livro, ele foi escrito entre 1925-26, embora sua descoberta seja de 1990, no arquivo unificado do Comintern e do Partido Comunista da União Soviética (PCUS). Para Löwy que prefacia a edição brasileira (apud LUKÁCS, 2015, p. 18), a revanche de Lukács representa um "exercício 
poderoso de dialética revolucionária, decisiva do oposto à variedade criptopositivista de 'marxismo' que logo se tornaria a ideologia oficial da burocracia soviética. A importância revolucionária decisiva do fator subjetivo na dialética histórica de sujeito-objeto".

Löwy entende que as posições de Lukács não combinam com as adotadas por exemplo em Moses Hess (1926), o que confirmaria que a publicação deste texto foi posterior ao Reboquismo. Ambos trabalhos apresentam em comum uma visão realista.

Moses Hess apresenta uma reconciliação com a realidade, enquanto Reboquismo é uma resposta aos jovens e influentes comunistas, Laszlo Rudas e Abram Diborin, acusados de fazer do marxismo uma ciência burguesa, de tendência "semipositivista e não dialética", em que os fatores objetivos assumem um papel ativo em relação aos "fatores subjetivos e revolucionários do processo histórico" (LÖWY apud LUKÁCS, 2015, p. 18). Reboquismo e Dialética apresenta uma análise realista e dialética da consciência de classe e da relação entre sujeito e objeto na práxis social do momento revolucionário, se situando como uma produção transitória ou introdutória à formação marxista de Lukács.

Em síntese, HCC é o primeiro ensaio marxista do autor e apresenta problemas graves tanto do ponto de vista do movimento socialista quanto da dialética marxista. Na edição de 1974, Lukács diz que em 1933, em seu itinerário para Marx, o livro reuniu os escritos mais significativos do período 1918-1930, mas com limites de ensaio, sem relevância para pensar a atualidade a que remetem as polêmicas levantadas: "as tentativas empreendidas para captar correctamente a essência do marxismo podem ainda hoje ter um certo alcance documental, se se adotar uma atitude suficientemente crítica, tanto a seu respeito, como a respeito da situação presente" (LUKÁCS, 1974, p. 349).

$\mathrm{Na}$ fase de produção de HCC o autor se dedicava ao estudo do pensamento de juventude de Hegel em busca das fontes da dialética de Marx, estudo que também será base da segunda tese filosófica de doutorado do autor, realizada durante seu exílio em Moscou. Da tese resultou uma das suas melhores produções, O Jovem Hegel, cuja publicação foi autorizada pelo partido em 1948, em Zurich, Suíça, dez anos após a conclusão. Neste texto, a relação entre sujeito e objeto ganha realce no capítulo sobre "o trabalho e o problema da teleologia"; está é entendida como uma categoria do trabalho, significando a representação antecipada na mente, da práxis social, o trabalho, a ser realizado de forma subordinada a uma finalidade, determinando por sua vez, também a forma e os meios do trabalho (LUKÁCS, 1981a, p. 77).

Lukács explica na resposta aos seus críticos a identificação entre sujeito e objeto como interação, pensamento que persiste na Ontologia, como também nos escritos políticos sobre a democratização, originalmente produzidos em 1947. Vejamos como ele explica a questão da interação dialética entre sujeito e objeto. Ele aponta a subjetividade como parte orientadora do processo objetivo, com a ressalva de que ela repercute somente na práxis e como "instante", momento de ação do sujeito. Este aspecto subjetivo da práxis deve ser entendido e levado a sério na política do marxismo, da mesma forma que o fator objetivo, entende Lukács. "Depois que a ação foi levada a cabo, o fator subjetivo volta a integrar-se à série dos fatores objetivos. Assim, para cada partido, seu próprio desenvolvimento ideológico - o proudhonismo na França, o lassallismo na Alemanha - constitui um fator objetivo" (LUKÁCS, 2015, p. 42).

Lukács (2015) é imperativo ao considerar que não seria possível sem o fator subjetivo "ativo e consciente", conceber a ideia de Lênin sobre as exigências práticas ao partido, prévias à revolução (p. 43). Essa defesa traz implícita uma argumentação que tem efeito parecido também no texto contemporâneo: Lênin. Um estudo sobre a unidade do seu pensamento (LUKÁCS, 2012).

Numa autocrítica a este texto, o autor aponta traços de um sectarismo messiânico, como também o mérito de enfrentar problemas que no marxismo eram evitados, além de adequação à teoria de Lênin. Quanto ao problema do estranhamento, que mais tarde será aprofundado na Ontologia do Ser Social, Lukács aponta na autocrítica de $\mathrm{HCC}$ uma ausência da dialética entre homem e natureza. O que já manifesta, nos parece, uma superação do idealismo.

Para ele um "defeito ontológico fundamental" foi ter entendido e explicitado como o Ser, somente o Ser social. Ele reconhece a falta da dialética da natureza em seu pensamento, ou seja: a "universalidade do marxismo que faz derivar da natureza inorgânica a orgânica, e desta, através do trabalho, a sociedade" (LUKÁCS, 1986, p. 46). 
Tertulian (1985) publica no centenário de Lukács um artigo no jornal Le Monde intitulado Georges Lukács et les tragédies du siècle. O filósofo pensava ter realizado uma ruptura na base de seu pensamento de juventude, mas a partir de uma análise séria, como observa Tertulian, mostra que: "a substância profunda de seus escritos de juventude se perpetuou, sofrendo uma metamorfose importante, nas obras da maturidade".

Um exemplo é a originalidade da democracia socialista na Hungria, a "ditadura democrática dos operários e camponeses", da qual Lukács fez parte, em contraste com a "ditadura do proletariado", do stalinismo contra a democracia socialista nesse país. Outro elemento substancial é o esforço em detalhar as formas em que a história incide no interior das obras literárias, como "uma nova hermenêutica literária, fundada na unidade de pontos de vista tradicionalmente opostos, sócio-histórico e estético". Lukács representava "uma virtuose da compreensão intuitiva e uma análise contundente da evolução das sociedades", o que se observa em A Grande Estética (1963) onde a arte tem a particularidade de representar uma das mais nobres manifestações humanas. E, quanto à Ontologia do Ser Social (escrita entre 1964 e 1970), Tertulian entende como uma reconstrução dos suportes filosóficos do pensamento de Marx, porém sob influência da ontologia de Hartmann contra aquela de Heidegger.

Os impactos das críticas a Lukács não se restringem à atividade partidária, se estende também ao conjunto ortodoxo de sua obra.

São ilustrativas da fase entre messianismo e realismo, as Teses de Blum, que o filósofo assinou com o codinome clandestino, na condição de dirigente da ala radical do PCH, "estratégias políticas e sociais" ao II Congresso deste partido. Na contracorrente e radicalmente rejeitadas pelo sectarismo burocrático da ala oficial do partido, as teses recuperavam uma indicação do VI Congresso Internacional do Comintern (PCUS), tratando da passagem à "ditadura democrática", na resolução do PCH.

A condenação de Lukács que rendeu sua exclusão do partido, se deu por ocasião de uma missão política do partido em Budapeste, quando ainda exilado em Viena. Na reunião da direção em Berlim, as Teses foram desqualificadas como tendência "revisionista e liquidacionista". As longas férias ou o exílio em Moscou, de 1930 a 1931, possibilitaram-no dedicar-se à filosofia e aprofundar junto ao Instituto Marx, Engels e Lênin o pensamento destes autores, a partir do acesso aos textos inéditos, como A ldeologia Alemã e os Manuscritos econômico-filosóficos de 1844 (LUKÁCS, 1986, p. 46-47).

A política em Lukács, articulada ao seu pensamento filosófico, faz parte também da visão de Mészaroz (2013, p. 104), que em sua cronologia mostra que, em 1925, a atenção de Lukács "se dirige para a elaboração dos problemas da dialética marxista em relação aos fundamentos econômicos da sociedade capitalista, que ele antecipa em dois ensaios importantes - sobre Lassalle (1925) e Moses Hess (1926) - a problemática de O Jovem Hegel (1935-1938)". Nesse sentido, reiteramos, a genialidade da HCC era dada aos estudos sobre a dialética de Hegel, em busca de justiça em favor da originalidade deste filósofo, que na Alemanha é desqualificado em nome de uma tendência filosófica que Lukács denomina de irracionalismo moderno, inspirado em Lênin.

No período, ele passa a se dedicar aos efeitos nefastos que tem a filosofia das ideias, nos meados do século XIX, mas diferenciando o lugar de Hegel em relação à decadência ideológica, na qual identifica Nietzsche e Heiddeger, dentre outros clássicos. Esse esforço compreende sua capacidade em diferenciar a ontologia de Marx e, com isso, a elevando em novos patamares, através de sua principal obra de maturidade.

Neste propósito, é importante ainda trazer as considerações de Lukács sobre a dialética em Lênin, que ele publicou em 1951 em outro texto, do qual tratamos a seguir. A influência de Lênin sobre o pensamento político de Lukács é aprofundada desde o exílio de Viena, sobretudo no que tange à relação entre sujeito e objeto na práxis revolucionária.

No domínio da filosofia, Lukács publica em 1954, na Suíça, em seu exílio de maturidade, Existencialismo ou Marxismo? Este texto significa uma parte de estudos mais aprofundados contra a tendência contemporânea da filosofia. Segundo seu editor de 1961, trata-se de um estudo obrigatório aos interessados na evolução da filosofia moderna. Suas observações indicam que depois de quinze anos, declarando não ter disponibilidade de tempo para dedicar-se à tarefa de revisão de HCC, o autor decide mostrar os problemas de fundo da filosofia marxista, no capítulo "A teoria leniniana do conhecimento e os problemas da filosofia moderna" (LUKÁCS, 1961, p. 236-290). Esse texto nos parece parte do seu pensamento maduro, mesmo que ainda 
jovem marxista, onde resgata na estrutura dialética da prática, a fonte do conhecimento, herança de Lênin que relacionamos à essência ontológica da política.

Lênin deixa claro, diz Lukács, que a crise do pensamento burguês sobre o sujeito do conhecimento abre espaço para o irracionalismo. A razão é a única orientação do conhecimento "adequado" na filosofia dos séculos XVIII e XIX, mas, a partir de então, as sensações, experiência vivida e sentimentos, passam a fazer parte da falsa hierarquia de elementos necessários ao conhecimento da realidade objetiva, da qual nem Hegel teria escapado totalmente. O que o autor quer dizer é que a dialética foi abandonada na medida em que se permitiu um escamoteamento de suas relações entre a razão e o entendimento, estabelecidas por Kant.

Hegel herdou esse mesmo traço, tornando-se expressão superior de tais entraves através de seu idealismo. Os procedimentos utilizados para associar a realidade objetiva ao objeto imediato como instância inferior, por via do solipsismo e "mitos nebulosos do pseudo-objetivismo", escamotearam a própria realidade. Esse seria o método utilizado pela divisão capitalista do trabalho, que gera estigmas próprios das teorias burguesas, impedindo a realização do homem em sua "totalidade e em sua unidade".

Lênin combate tanto aquelas tendências que exageram na supremacia da razão quanto as que sustentam o irracionalismo moderno. Ele insiste na relatividade da divisão entre matéria e espírito, ou da abstração da polêmica sobre a preponderância da gnosiologia, pelas consequências metodológicas (LUKÁCS, 1961, p. 285-286)

A relatividade dos fatores objetivo e subjetivo, material e espiritual, sua unidade dialética suas transformações mútuas se manifestam sob um aspecto concreto aqui onde surge a questão central de toda teoria do conhecimento leninista: aquela da atividade prática do homem, enquanto critério decisivo do conhecimento (LUKÁCS, 1961, p. 286).

Para Lukács (1961), Lênin coloca sobre um novo plano as questões essenciais da teleologia, ao fazer da prática o critério do conhecimento. Ele explica que, para Hegel, "a relação entre o projeto humano e a realidade à qual ele se aplica é ainda puramente exterior. Para Lênin, é absolutamente claro que o projeto humano não é independente do real senão em aparência" (p. 287).

Por isso, o método de Marx apresenta respostas bem sistemáticas para estas questões e somente ele pode explicar como o trabalho produtivo que é atividade humana básica, cujas ferramentas utilizadas distinguem o homem do animal, se "metamorfoseia pela prática consciente da conquista progressiva da natureza em formas abstratas do pensamento" (LUKÁCS, 1961, p. 287). Esta abstração não é oriunda do espírito, mas da evolução histórica do homem em suas ações e interações reais presentes em todo o mundo. Lênin mostra assim, a via certa para a "reconquista da totalidade humana" ao entender que, em todos os pontos de vista o conhecimento é inseparável da ação prática e do trabalho. Para o autor esse humanismo de Lênin não se recua em face do anti-humanismo do capitalismo, mas "é aquele envolvido na luta dos homens, no conhecimento e na conquista do mundo, quem trabalha, sendo ao mesmo tempo teoria e prática, o nascimento do homem novo, que reencontrou sua totalidade humana" (p. 287-290).

A importância histórica desse escrito explica a resistência que encontrou na Europa sua obra filosófica de maturidade. No entanto, a Ontologia do ser social é resultado de um percurso de reflexão política sobre o socialismo e também um esboço das relações ainda não inclusas da ontologia sobre a ética marxista, que seria o objetivo final de sua obra filosófica. A política seria a essência da ontologia do ser social, a práxis política cotidiana e radicalmente democrática, de cujos pressupostos faz parte e é constituído em permanência, o conhecimento científico e filosófico.

\section{História e Política na evolução do pensamento de Lukács}

Nas universidades de Berlim e de Heidelberg, Lukács estabelecera relações com filósofos, professores e escritores importantes, dentre os quais Rickert, Lask, Dilthey, Husserl, Jaspers, Heidegger, Korsch, Bloch, 
e os sociólogos Max Weber, Simmel, Maneiem, escritores como Gundlf e Thomas Mann, tomando contato com tendências filosóficas, como o neokantismo e a fenomenologia, o hegeliano-marxismo, a sociologia compreensiva (AXELOS apud LUKÁCS, 1960). O primeiro livro A Metafísica da Tragédia foi publicado em 1908, mas Lukács ficou conhecido a partir de A Alma e as Formas (1911), publicado em alemão. $O$ autor viria mencionar no prefácio deste livro, em 1962, o contexto que o gerou, o início da Primeira Guerra Mundial e sua inconformidade e desespero frente à realidade mundial e à sociedade burguesa, desejando a queda da monarquia na Europa Central.

Lukács (1974) explica que, em Teoria do Romance, seu utopismo era "altamente ingênuo": "[...] a esperança de a destruição do capitalismo e da ruína, identificada a esta destruição, das categorias econômicas e sociais privadas da vida e inimigas da vida, poderia sair de uma vida natural, digna de ser vivida pelo homem" (p. 350). Sua visão era de um anticapitalismo romântico, tanto na forma política quanto filosófica. Ele não conhecia Marx, a não ser pela ótica sociológica de Max Weber e Simmel. No período da Primeira Guerra Mundial, ele diz ter aprofundado a filosofia de Marx, "mas desta vez animado por um interesse filosófico geral: encontrava-me sob a influência de Hegel” (LUKÁCS, 1974, p. 350).

se minhas recordações deste período são exatas, encontro simultaneamente no meu universo intelectual de então, por um lado, tendências para a aquisição do marxismo e para a atividade política, por outro, tendências para uma intensificação contínua de problemáticas éticas, puramente idealistas (LUKÁCS, 1974, p. 350).

O anticapitalismo do filósofo, como ele próprio diz, encontra-se na origem de uma "crítica dos horrores e da barbárie do capitalismo nascente, às vezes mesmo de uma primeira forma de crítica socialista em relação a este capitalismo" (LUKÁCS, 1974, apud LÖWY, 2016, p. 114). Esta crítica, pelo fato de se contrapor às extremas injustiças da burguesia no capitalismo que floresce, não parece negativa ao autor. Ele conclui o livro revelando a esperança de uma outra sociedade "um novo mundo", identificada nas obras de escritores russos, como Tolstöi e Dostoïevski (LÖWY, 2016, p. 113-114).

Oldrini (1986) observa na maturidade uma impressionante evolução no pensamento de Lukács.

[...] o utopista messiânico, partidário do exclusivismo de uma revolução puramente proletária, se transforma em teórico da 'ditadura democrática' e da política de Frente popular; aquele que negava, em filosofia, a dialética da natureza e, em estética, a teoria do reflexo da realidade objetiva dela se torna um partidário, ao menos potencialmente; o ensaísta refinado dos anos de juventude se transforma no ponto de vista do estilo igualmente, um pensador sistemático, torna o autor de obras solidamente estruturadas, onde o ordenamento e a construção são tão amplas que parece às vezes, mesmo prolixo (OLDRINI, 1986, p. 115-116).

Em Correspondence de Jeunesse (1908-1917) (LUKÁCS, 1981) são registradas a estima e as trocas de natureza intelectual realizadas entre reconhecidos e também jovens intelectuais de sua época, dentre os quais Paul Ernest, que faleceu muito precocemente, Léon Popper, Karl Mannheim, Thomas Mann, Ernest Bloch e Marx Weber. O caminho escolhido por Lukács foi muito diferente das tarefas clássicas daquela elite acadêmica, nas "gloriosas tradições universitárias", como refere Tertulian (2016).

O pleito a uma vaga de professor efetivo não chegou ao final. Em Heidelberg, Max Weber foi seu mestre e amigo, a quem esperava pelo brilho de suas ideias, um lugar na academia. A tese de Lukács inscrita ao pleito da vaga de professor, já continha os pressupostos de sua estética, entretanto, o material foi arquivado por questões conjunturais e políticas: Lukács aderira depois registrar a tese à revolução húngara, engajando-se no governo socialista.

Também em Heidelberg, de 1913 a 1917, ele frequentou os meios intelectuais necessários e buscou as fontes de uma pesquisa filosófica que foram importantes em vários de seus textos futuros, a exemplo do não menos polêmico $A$ Destruição da Razão (2010; 2012), que publicado tardiamente contribuiu para as calunias que enfrentou nos anos 1940 , sendo afastado do partido e proibido de publicar, tratado mais abaixo. Ou seja, é neste período de estudos que ele aprofunda os pensamentos de Schelling, 
Schopenhauer, Kierkegaard e Heidegger, dentre outros. Tertulian (1980) levanta um paradoxo em Lukács: "enquanto suas obras de juventude eram cercadas sobretudo pela inteligentsia ocidental, de elogios com freqüência desmesurados, [...] sua obra de maturidade se impunha muito lentamente e com certa dificuldade" (p. 285-286).

Resgatando as fontes da evolução do pensamento de Lukács, quando jovem será marcado por uma oposição radical entre capitalismo e socialismo, entre o bem e o mal, onde o rigorismo ético permanece no período de transição e reflete diretamente na política. Será quando ele participa na Hungria da Primeira República Soviética, a República dos Conselhos, ocupando o cargo de Comissário para a Cultura Popular no Ministério da Educação e Cultura.

Neste momento ele se caracteriza pelo radicalismo de esquerda e o idealismo ético. Suas fontes até 1921 são as ideias filosóficas de Fichte, Hegel, Marx, Dostoïevsky, Sorel, Rosa Luxemburgo, Pannekoek, Henriette Rolant-Holst, Lênin, etc., e politicamente, por Erwin Szabo. Para Löwy (1976), o idealismo ético de Lukács, quando superado, não reproduz as fontes mencionadas nem o neo-hegelianismo, expressava antes de tudo, uma simbiose entre "messianismo, escatologia, moralismo revolucionário, ética absoluta e idealismo neo-hegeliano". Significava uma tendência seguida pelo grupo significativo de intelectuais que o acompanhava na linha radical do PCH (TERTULIAN, 1980, p.171-172). Será perceptível tal característica num discurso memorável, por ocasião do congresso de jovens trabalhadores, quando Lukács (2014) no seguinte extrato de texto, julga que de acordo com os interesses proletários, aqueles jovens deveriam:

[...] levar adiante uma luta da política livre de compromisso, totalmente pura, intacta. Este espaço se encontra na alma da juventude. Creiam em mim, em cada luta e em cada discussão, o mais importante é que existe um espaço livre de compromisso, em que a luta do proletariado se desenvolva de forma totalmente pura, sem compromisso algum (LUKÁCS, 2014, p. 70).

No mesmo discurso explica a inversão necessária do método de atuação ao tomar o proletariado o poder e a economia, assim como, da irreverência presente nos jovens trabalhadores, a ser mantida mesmo após alcançarem o fim desejado pela classe. Seu programa no governo era ousado, radicalmente revolucionário e causava polêmicas na sociedade pelas mudanças que começava a imprimir na gestão da educação e da cultura, pondo em questão a tradição familiar, os limites dos valores religiosos e suas consequências na formação da infância. Ele convocava as crianças e as mulheres húngaras a se juntarem a uma rebelião contra o grau de exploração do espírito pela sociedade burguesa. Um dos panfletos será intitulado A Mulher e o Sistema Social Comunista (LÖWY, 1976, p. 178-179).

A queda da Primeira República Soviética da Hungria, em 21 de março de 1919, leva Lukács a sua primeira exclusão da política, formando uma resistência clandestina que durou dois meses, antes de fugir para a capital austríaca, Viena, onde os comunistas húngaros eram acolhidos pela esquerda no governo e, particularmente, internados em hospital psiquiátrico. Antes de ser efetivamente preso e do enforcamento de seu amigo Otto Korwin, ex-chefe da segurança comunista, Lukács foi acolhido por uma baronesa judia que viria a terminar num campo de concentração. Ele partiu para Viena, foi preso no Castelo de Karlistein, destino de Bela Kun, chefe do governo deposto, mas diferente deste ele foi poupado de internação psiquiátrica e da deportação até 1923. Durante todo o período foi protegido por amigos do meio cultural, que o resguardaram do enforcamento e morte, ao contrário de dezenas de comunistas, pelo ditador fascista, chamado Horty.

Uma liderança desse movimento que protegeu Lukács foi Thomas Mann, a quem a crítica por ele publicada sobre o livro Montanha Mágica, rendeu notoriedade tanto ao escritor e quanto ao crítico. Neste ano o filósofo escapou da lista de Horty da qual foi vitima o presidente do PCH, o amigo e escritor Landler. Declarado sem residência fixa pela polícia, Lukács manteve discretamente e clandestinamente sua fidelidade ao PCH no pais vizinho, até 1929.

Diante das ameaças, fugiu para a Alemanha do leste, onde passou dois anos, até a invasão das tropas de Hitler, dando origem ao exílio de Moscou (BOURDET, 1972, p. 44-51). Em síntese, a expe- 
riência política levou ao amadurecimento de Lukács e à ruptura de seu rigorismo ético pelo realismo político presente em HCC e demais textos do exílio de Viena, como observamos anteriormente (LÖWY, 1976).

O exílio em Moscou se passa após o período de expurgos do PCUS (Partido Comunista da União Soviética), dos quais Trotski foi vítima em 1929. O domínio de Stalin cresce após sua vitória sobre as tropas de Hitler, no período da Segunda Guerra Mundial. Ao mesmo tempo, se verifica no partido e no governo, desde a morte de Lênin, em 1924, um recuo do pensamento de Marx, repercutindo no movimento da Internacional Comunista e gerando o desligamento de numerosos filiados. Por outro lado, a violência e os conflitos acompanhavam o processo de expansão socialista no leste europeu, havendo enfrentamentos conforme as particularidades políticas e constituição interna do partido em cada país.

Em 1945 Lukács volta à Hungria do segundo e mais longo exílio em Moscou (1931-1945). Incentivado pela abertura política, assume papel ativo na Frente Popular Patriótica, uma nova tática no combate às tropas de Hitler. Entusiasmava o autor aquela democracia popular que ele interpreta na "nova democracia", baseada no convencimento e debate de ideias, ou o que ele chamava de "política frentista".

Como recupera Netto, ele confessa que a autocrítica não era problema: "era evidente que esta autocrítica (decorrida da derrota das Teses de Blum) não podia ser levada a sério: a mudança da opinião fundamental que sustentava as teses [...] passou a ser doravante o fio condutor para minha atividade teórica e prática" (NETTO, 2011, p. 29). Nesse período Lukács recupera seu posto na Universidade de Budapeste, na direção da academia de ciências e, através de novos textos e conferências na Europa, entre 1946-1949, Lukács difunde a ideia de paz e de democracia. Mas essa proposta não era aceita pelos membros do partido que apoiavam o modelo autoritário de Stalin.

Uma aliança das forças democráticas do período da República dos Conselhos é realizada com um falso fim de fazer uma transição socialista. Matyas Rakosy assume o poder do partido em 1948-1949, realizando condenações, a exemplo do enforcamento de Lazlo Rajk, acusado de agente imperialista. As consequências da repressão recaem sobre Lukács, que é submetido a uma série de difamações que reativam a questão em torno às Teses de Blum, resultando em sua deportação para a Romênia onde ele ficará exilado por um ano. Em seu retorno, a condição não aceita por ele para reingresso ao partido era a autocrítica. Em represália, o filósofo fica proibido de publicar seus textos, além de sofrer novos processos caluniosos.

Em 1956, no XX Congresso do PCUS foram apresentadas demandas que lembravam a "nova democracia" de Lukács no pós-guerra, levando-o novamente a ocupar o cargo de Ministro da Cultura do Governo Nagy, do qual ele renúncia após a retirada de seu país do Pacto de Varsóvia. Esse fato desencadeia a invasão das tropas de Stalin juntamente com o Pacto de Varsóvia e, juntas bombardeiam Budapeste durante uma semana (NETTO, 2011, p. 19).

Nesta última fase de isolamento político, Lukács escreveu e publicou várias obras literárias, como: $O$ realismo russo na literatura universal; Tomas Mann (1949); Realistas alemães do século XIX (1951) e Balzac e o realismo francês (1952). Mas a política ganhou maior amplitude a partir de 1951, quando Lukács perde todos os espaços conquistados, odiado pelos amigos. As acusações aos seus escritos e posições democráticas de base, não apenas deixam marcas profundas pelo fato de o afastar do partido. Ele é estimulado a aprofundar a dialética na vida cotidiana, como processo de socialização das necessidades e práxis social definidora da consciência que se constrói na democratização do cotidiano, na ampliação da liberdade como conquista teórica e prática.

Assim, a essência do pensamento de Lukács reside na unidade dialética da sua obra, constituída pelo contexto histórico, a fidelidade ao partido e ao pensamento original de Marx. A realidade e o compromisso diante da necessidade de estratégias socialistas imediatas, afirmavam a tarefa de estabelecer uma crítica no domínio da filosofia, considerada na perspectiva de Marx uma ferramenta revolucionária para impulsionar as lutas socialistas. Era necessário voltar ao pensamento original destes clássicos, lideranças do partido, fortalecer a crítica marxista da sociedade e da ciência burguesas. Lukács se propõe a resgatar a dialética como conhecimento produzido a partir da prática concreta. 


\section{Política, cotidiano e democratização}

Introduzimos algumas críticas que Lukács expõe em relação à ideologia burguesa, que julga uma tarefa decisiva do marxismo. Tarefa esta que lhe permite enfrentar o positivismo no interior do movimento, onde as ideias de Lênin continuam sendo fundamentais.

Ao publicar os escritos políticos de sua fase madura, longamente afastado da política no cotidiano, o filósofo revela uma perspectiva democrática que é recuperada das experiências políticas socialistas e da reflexão filosófica acumulada à luz do pensamento de Marx, Engels e Lênin. Adotando a democracia como base, processo ou história da práxis revolucionária, Lukács aborda os limites no processo de construção do socialismo pelo PCUS, entre os quais a burocracia, mostrando o significado do pensamento de Lênin para além das decisões táticas.

O autor explica que não havia nenhum interesse no partido em "garantir efetivamente o desenvolvimento socialista por meio do aperfeiçoamento e da consolidação dos germes de democracia socialista existentes". A tática era interpretada por Lênin de forma realista, por ser "um analista excepcionalmente agudo das situações concretas e das concretas decisões alternativas que resultavam de tais situações" (LUKÁCS, 2012, p. 25). Mas, como um autêntico marxista, as decisões significam "sempre e somente momentos parciais do grande desenvolvimento histórico do gênero humano". Outro elemento importante é que Lênin sintetizava "as tendências históricas do presente" como "fundamento de uma estratégia capaz de determinar a práxis" (LUKÁCS, 2012, p. 25), embasado previamente em pesquisa científica e histórica, o que não mais será considerada uma condição, após a morte daquele líder da revolução soviética.

Com Stalin a tática ganha prioridade, tanto em questões imediatas quanto em decisões de mais amplo espectro e sempre sem o conhecimento histórico e científico, que quando recuperado, apenas justifica a tática adotada. O filósofo identifica nessa tendência, os traços da social-democracia e de um movimento ideológico iniciado por Bernstein e seguido nos programas mais recentes dessa corrente, que vão desembocar num antimarxismo, adaptação de técnicas manipuláveis pelos partidos da burguesia.

Se, antes do Congresso de 1903, Lênin já usava como fonte da práxis a teoria marxista, seus sucessores não apenas abandonam tal orientação como dão novo aspecto ao tema, agora numa perspectiva formal e linear. Esta orientação traduzia uma tendência do movimento revolucionário, que tinha dificuldades de estabelecer uma unidade entre a teoria de Marx e os encaminhamentos práticos e táticos, que, via de regra, estão relacionados à liderança intelectual, cuja tradição fora iniciada pelo teórico alemão no partido social-democrata, sucedido por Engels e tão somente após a sua morte é que tal confronto toma força.

Lênin teria sido, na visão de Lukács, o intelectual, como Marx e Engels, a incorporar o papel de mediação do marxismo no movimento socialista russo com a organização política. Essa tendência no movimento, de incapacidade de pensar o socialismo a partir do ponto de vista nuclear de Marx, é uma lacuna objetiva que Stalin procura ocupar, desenvolvendo estratégias que o colocam no lugar de Lênin e Marx, mas distorce o método original deste. As consequências sobre a práxis, Lukács sintetiza, ao afirmar:

De certo, a extensão, a intensidade, o conteúdo, a direção, etc. da práxis são definidos e determinados, em cada situação concreta, pelo grau de desenvolvimento econômico da condição social específica. A parcela do trabalho socialmente necessário que é convertida em trabalho excedente socialmente liberado pela revolução proletária, e que pode assim ser utilizado para esta finalidade de dar sentido à atividade do homem, é determinada pelo desenvolvimento econômico (LUKÁCS, 2011, p. 144).

A política e o cotidiano são exemplificados de forma interligada aos conselhos operários como um pressuposto da democracia popular, que defendera nas referidas Teses de Blum. Para o autor, a política não se confunde com vida cotidiana imediatamente dada, ela é antes um conjunto dado pelas circunstâncias, o contexto da realidade, e a capacidade de se fazer escolhas que melhor atendam às condições existentes e ao poder que detém os dirigentes sobre a realidade possível de ser transformada pelas forças socialistas, então constituídas. Ele renunciou à vida burguesa, mas não abdicou de sua cultura, a alimentou para defender na política, de fato e objetivamente, uma democracia. 
Lukács acreditava que, a partir do cotidiano, devia se estabelecer um embate ideológico em nome do poder do povo, ou seja, democratizar o cotidiano, nas relações de trabalho, apropriando da riqueza construída e formando novas consciências, capazes de superar os atributos de uma consciência dada pelo poder, que no capitalismo tem na propriedade individual, um pressuposto para acesso à cultura.

Em seu pensamento político a cotidianidade tem um conteúdo filosófico da maior importância, significando a essência mesma do pensamento maduro de Lukács, significando a base de uma nova cultura, densa de historicidade, que gera novos hábitos, oriundos de uma socialização das relações de trabalho e de produção. Democracia significa cultura, educação, trabalho, componentes ontológico-sociais, conquistados de forma coletiva na e pela política, que se faz fazendo, na imersão, no conjunto, pela práxis humana, pela teleologia.

A democracia é um complexo de atribuições, lutas e conquistas, embates históricos para se impor novas formas de realização do trabalho, de organização dos interesses dos trabalhadores, sem cristalizar relações viciadas pelo individualismo presente na cotidianidade. Estas relações não dominam totalmente o homem, uma vez que a solidariedade no trabalho, as organizações operárias, são esferas de socialização, que orientam a ação do trabalhador em seu processo de trabalho, estabelecendo relações democráticas.

Lukács pensa aqui num progresso continuo da humanidade, porém sob formas coletivas de apropriação do conhecimento e da riqueza material produzida. Essas ideias estão presentes no texto sobre "As tarefas da filosofia marxista sobre a Nova Democracia" (2007), uma palestra realizada em dezembro de 1947 em Milão, por ocasião da "Conferência Internacional dos Filósofos Marxistas".

O filósofo marxista, ao abordar a cultura, menciona a necessidade de mudanças na formação de novos quadros, porque nem tudo se aprende a priori, havendo condições para que esta nova democracia se realize. Somente transformações nas condições concretas de vida do povo podem gerar uma nova relação desta com o Estado e a economia e, portanto, uma outra consciência.

Ao mesmo tempo que afirma a ideia de uma sociedade nova, Lukács remete à uma nova cultura, ponderando sobre o adjetivo novo e o risco alertado por Lênin de idealização ou abstração em nome do absoluto. Trata-se antes, de uma continuidade dialética, um "salto qualitativo", "algo que contém simultaneamente a "descontinuidade", a formação da novidade qualitativa, o salto" na continuidade elabora sempre uma nova cultura. Parafraseando Hegel, no ensinamento materialista "as revoluções são momentos decisivos da continuidade histórica" (LUKÁCS, 2007, p. 62-65).

A democracia socialista foi representada após 1917 nos conselhos ou sovietes, inspirados na Comuna de Paris em 1871 e retomados em 1905 na Rússia. Lukács mostra as contradições que podem esconder um movimento de massa, pelo caráter espontâneo e o contexto de sua eclosão.

Primeiramente, ele nota que a força dos conselhos é derivada da capacidade de "envolver os homens em sua concreta vida cotidiana, em seu local de trabalho, em suas casas, etc." (LUKÁcS, 2007, p. 62-65). para progressivamente ou mesmo de repente dar um "salto", adotando uma atitude "revolucionária" em relação às questões maiores presentes na sociedade. Disso resulta a lição de passagem da vida cotidiana ou da espontaneidade à grande política, podendo ocorrer de forma instantânea num dado contexto, diferente de épocas onde as exigências sejam menores, tal como a urgência de paz em um período de intenso conflito, como em 1917.

Lukács retira da experiência de expansão dos sovietes no período de Stalin, a oposição entre espontaneidade e o "agir consciente", onde as ações espontâneas são subestimadas, mas Lênin as interpreta como um germe da consciência. As revoluções são momentos de elevação da consciência dos homens, entretanto condicionadas à uma única possibilidade: que as grandes questões passem a constituir também um problema cotidiano na vida da população, tornando parte de suas ações e não um mero conhecimento sob poder de especialistas e lideranças.

Na revolução de 1917, essa experiência ocorreu nas questões iminentes da sociedade e do Estado, quando o partido comunista era dirigido por Lênin. Observa-se o peso de Lênin na visão de Lukács, mas também uma superação.

Por exemplo, ao apontar os limites dessa constituição democrática na realidade pós-1917. O risco iminente de um aprofundamento dos conselhos seria a deformação burocrática, quando na base da 
organização tem um problema estrutural fundamental, como o atraso econômico do império russo, que o impedia e tornava impossível uma aliança entre camponeses e operários para sua superação. Isto não se resolvia com o "entusiasmo revolucionário, nem mesmo o mais sincero e resoluto", menciona Lukács nos discursos de Lênin (LUKÁCS, 2011, p. 145-147).

Na apreciação de Netto,

Lukács foi um pensador político, não um pensador da política. Esta determinação não retira da sua concepção política a importância, como tampouco minimiza a sua significação; apenas permite apontar o espaço restrito em que decorre a sua reflexão política". Seus textos originam de "exigências decorrentes das concepções teórico filosóficas e a injunções do seu protagonismo como sujeito político" (NETTO apud LUKÁCS, 2011, p. 21).

Feita tal observação, pode-se sintetizar a ideia de democracia socialista como "órgão da autoeducação do homem", no sentido de criar "as bases do comunismo no ser e na consciência", tendo como mediação a economia, que por sua vez é determinada pela ideologia. Embora a entenda como uma novidade no socialismo, Lukács (2011, p. 141-142) identifica um problema ao qual cabe tão somente à atividade dos trabalhadores dar resposta. A ideologia seria, na Contribuição à crítica da economia política, de Marx, um "meio social" que permite aos homens a concepção do nível de contradição presente na economia.

Diz o autor que o problema é dado à "lei necessária objetiva que faz surgir contradições entre forças produtivas e relações de produção". A ideologia é um "conjunto de meios através dos quais os homens tornam-se capazes de tomar consciência de tais conflitos e de enfrentá-los na prática" (LUKÁCS 2011, p. 141-142).

A solução deve estar num processo, em cuja práxis dos trabalhadores eleva-se à consciência, conforme Lênin pensava a educação, na superação do analfabetismo, na economia Russa. Tal processo prática levaria à superação do subdesenvolvimento, dando condições aos indivíduos para resolverem as contradições da vida cotidiana, ampliando e aprofundando as condições de aperfeiçoamento do indivíduo, após romper o domínio de uma classe sobre os meios de produção e socialização dos mesmos. A educação é, assim, um processo determinado objetivamente, uma conquista racional do homem em relação às transformações necessárias à sua verdadeira realização.

A sociabilidade é um dado que acompanha, desde o início, o processo pelo qual o homem se torna homem; mas, nas sociedades de classe, esta sociabilidade se apresenta à crescente interioridade dos homens como uma objetividade alienada. Em sua máxima e mais profunda expressão, a democracia socialista (...) transforma os produtos aos quais os homens chegam inconscientemente (...) em objetos produzidos conscientemente pelos próprios homens (LUKÁCS, 2011, p. 144).

Infranca (2005) observa em Trabajo, Indivíduo, história. El concepto de trabajo en Lukács, que a política no último Lukács compreende também a cultura desenvolvida a partir do "trabalho bem feito", o que acompanha desde a origem até a crítica cultural do trabalhador no processo de produção, reposicionando o problema da aproximada relação entre cultura e democracia. O conhecimento dos complexos problemáticos que envolvem o processo de produção exige do trabalhador uma "intervenção crítica e o controle" deste processo. Diz o autor, que:

Uma cultura operária nasce no espaço de trabalho, porém logo se estende ao resto da sociedade, dado que o trabalhador leva sua própria experiência de trabalho e sua prática em geral para sua participação na vida comunitária. Caem as barreiras entre trabalho e comunidade e também entre trabalhador e cidadão, cada um deles em relação recíproca de crescimento e progresso (INFRANCA, 2005, p. 119). 
Apontamos algumas considerações a serem aprofundadas. Parece-nos importante destacar a importância da relação entre ética e política em Lukács, que remete às suas reflexões sobre o trabalho, mas que ele não conseguiu aprofundar dentro de sua obra final. Lukács (2007) em "A responsabilidade social do Filósofo", texto correlato à Ontologia do Ser Social, fala da importância do marxismo para o avanço do conhecimento sobre a ética, inicialmente por sua distinção das teorias sociais que coisificam o indivíduo, dando-lhe uma legalidade própria e inumana.

O marxismo permite pensar as leis da economia como objetivas e definidas pelo homem, ou como complexo de relações do homem em interação com a natureza. Estas leis sintetizam ações humanas, por meio de complexos e mediações, contrastando com Hegel onde "as formas mitológicas alcançam aqui uma objetividade científica". Para Lukács o trabalho "só pode adquirir um significado universal se considerado literalmente como trabalho físico (que é, ao mesmo tempo, também espiritual), ou seja, se da ontologia do homem desaparece qualquer transcendência sobre-humana" (2007, p. 226-227). A dualidade dialética sempre dada à ética pelos homens ocorre, ao contrário, de forma natural e social. Citando Marx "O indivíduo é o ser social. [...] A vida individual e a vida genérica do homem são diversas [...]" (LUKÁCS, 2007, p. 228), e unicamente sua forma de realização, o movimento dialético das contradições, é passível de mudanças no curso histórico-social; o trabalho é o fundamento da unidade, da persistência e da mudança.

A política é fundamentada como espaço de criação e de reprodução da atividade humana em direção ao humano-genérico, ou como mediação prática, social e racional do processo que envolve o desenvolvimento humano, portanto está presente na pré-idealização ou na teleologia que direciona e almeja a realização humana, nas lutas pela igualdade e emancipação no plano concreto, contínuo e pleno.

\section{Conclusão}

Sintetizando, a democracia é parte do cotidiano, complexo do real que caracteriza as contradições na formação e emancipação do ser social. Lukács, em sua vida política, percebia essa complexidade e entendia a democratização como processo permanente, realizada continuamente. Isso responde e, ao mesmo tempo, coloca novas questões à sociedade civil, aos conselhos operários, à sociedade organizada em representações, elevadas a um plano superior por meio de frentes ou alianças que desenvolvam as condições para elevação das condições de vida, de acordo com as possibilidades objetivas. Sua concepção de ética e da política formam uma unidade na relação com teleologia, ideologia e práxis social.

O aprofundamento das contribuições da política em Lukács, requer uma dimensão dessa unidade entre política e filosofia, entre ética e ontologia. Nesse sentido, pode-se afirmar que sua concepção de ética fundamenta esta unidade, tornando-se construto do momento de elevação do ser social, o que compreende a práxis política enquanto totalidade histórica. A cultura não está separada desse complexo, ela é a própria política num plano elaborado e ao mesmo tempo, como processo de formação da consciência, complementar à subjetividade que se explicita na objetivação do trabalho e do ser social, como sujeito e objeto, objetivação e exteriorização.

Estas reflexões resultaram do longo percurso intelectual do autor, tendo como base fundamental as contradições do capitalismo, mediante a emergência da consciência operária enquanto classe, que necessita da dialética a partir da segunda metade do século XIX, como observa de perto Marx, para instituir uma nova cultura, o conhecimento necessário na antecipação das condições e alcance da emancipação humana no socialismo, uma "nova democracia".

\section{Referências}

AVRON, H. Lukács ou le Front Populaire en littérature. Paris: Editions Seghers, 1968.

BOURDET, Y. Figures de Lukács. Paris: Anthropos, 1972.

INFRANCA, A. Trabajo, Individuo, História. El concepto de trabajo en Lukács. Buenos Aires, Herramienta Ediciones. 2005. 
LUKÁCS, G. Histoire et Conscience de Classe. [S. I.]: Paris, 1960.

LUKÁCS, G. Existentialisme ou Marxisme? Paris: Editions Nagel, 1961.

LUKÁCS, G. História e Consciência de Classe. Estudos de dialética marxista. Porto: Publicações Escorpião, 1974.

LUKÁCS, G. Le Jeune Hegel I. Paris: Editions Gallimard, 1981a.

LUKÁCS, G. Correspondence de Jeunesse. Paris: François Maspero, 1981.

LUKÁCS, G. O Jovem Marx e outros escritos de filosofia. Rio de Janeiro: UFRJ, 2007.

LUKÁCS, G. Diálogo sobre O “pensamento vivido". Última entrevista de Lukács - Extratos. Ensaio. Filosofia, política, ciência da história, São Paulo, número especial, p. 13-108, 1986.

LUKÁCS, G. Lênin. Um estudo sobre a unidade de seu pensamento. São Paulo, 2012.

LUKÁCS, G. La destruction de la raison: Schelling, Schopenhauer, Kierkegaard. Paris: Editions Dela, 2010.

LUKÁCS, G. La destruction de la raison: Nietzsche. Paris: Editions Dela, 2012.

LUKÁCS, G. Táctica y Ética: escritos tempranos (1919-1929). Buenos Aires: Herramienta Ediciones, 2014.

LUKÁCS, G. Reboquismo e Dialética: uma resposta das críticas de História e Consciência de Classe. São Paulo: Boitempo Editorial, 2015. https://doi.org/10.36311/0102-5864.2017.v54n1.10.p136

LÖWY, M. Une Sociologie des intellectuels révolutionnaires. Paris: Presses Universitaires de France, 1976.

LÖWY, M. Le Romantisme (anticapitaliste) dans la Théorie du Roman. Lukács 2016: cents ans de Théorie du roman. Romanesques - Revue du Centre d'études du roman et du romanesque, Paris, n. 8, p. 109-126, 2016. https://doi.org/ 10.1515/arcadia-2017-0031

MESZAROZ, I. O conceito de Dialética em Lukács. São Paulo: Boitempo Editorial, 2013.

MESZAROZ, I. Socialismo e Democratização: escritos políticos 1956-1971. Rio de Janeiro: UFRJ, 2011.

OLDRINI, G. Le Mythe du Jeune Lukács. In: FURLAN, P. et al. Actes du Colloque du Goethe Institute. Réification et Utopie. Ernest Bloch \& Gyorgy Lukács. Un siècle après. Paris: Actes SUD/ Hubery Nyren Editeur, 1986. p. 115-129.

TERTULIAN, N. Georges Lukács: Etapes de sa pensée esthétique. Paris: Sycomore, 1980.

TERTULIAN, N. (1985, 24 de Maio) Georges Lukács et les tragédies du siècle. Le Monde.

TERTULIAN, N. Pourquoi Lukács? Paris: Editions Fundation des Sciences de I'Homme, 2016.

Recebido em: 11/03/2018.

Aprovado em: 08/11/2019.

Publicado em: 30/01/2020.

Correspondência para:

Universidade Federal Fluminense (UFF)

Escola de Serviço Social

Rua Alexandre Moura, 8 - São Domingos

24210-200, Niterói, RJ, Brasil

Autora:

LUCI FARIA PINHEIRO

Assistente Social, Doutora em Antropologia e Sociologia Política, Professora Associada III da Universidade Federal Fluminense (UFF),

Escola de Serviço Social.

Orcid: http://orcid.org/0000-0001-9112-0670

E-mail: farialuci@uol.com.br 